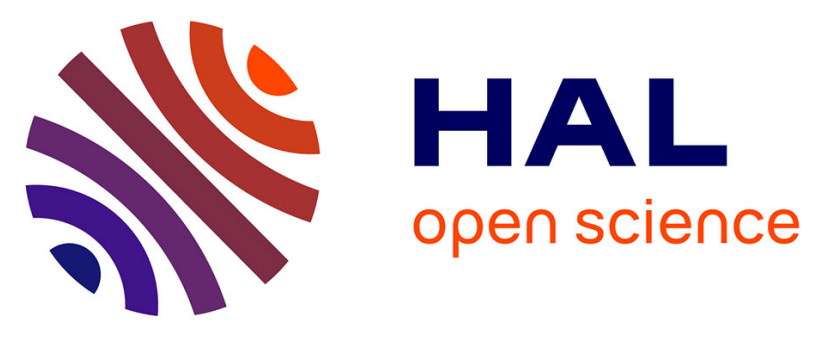

\title{
Development of $1 \mathrm{eV}$ InGaAsN PIN subcell for MJSC integration and space application
}

\author{
Maxime Levillayer, Sophie Duzellier, Hélène Carrère, Inès Massiot, Thierry
}

Nuns, Stéphanie Parola, Alexandre Arnoult, Christophe Inguimbert, Laurent Artola, Chantal Fontaine, et al.

\section{To cite this version:}

Maxime Levillayer, Sophie Duzellier, Hélène Carrère, Inès Massiot, Thierry Nuns, et al.. Development of $1 \mathrm{eV}$ InGaAsN PIN subcell for MJSC integration and space application. 47th IEEE Photovoltaic Specialists Conference (PVSC 47), IEEE, Jun 2020, Calgary (virtual), Canada. 10.1109/PVSC45281.2020.9300570 . hal-03012129

\section{HAL Id: hal-03012129 \\ https://hal.laas.fr/hal-03012129}

Submitted on 18 Nov 2020

HAL is a multi-disciplinary open access archive for the deposit and dissemination of scientific research documents, whether they are published or not. The documents may come from teaching and research institutions in France or abroad, or from public or private research centers.
L'archive ouverte pluridisciplinaire HAL, est destinée au dépôt et à la diffusion de documents scientifiques de niveau recherche, publiés ou non, émanant des établissements d'enseignement et de recherche français ou étrangers, des laboratoires publics ou privés. 


\section{Development of $1 \mathrm{eV}$ InGaAsN PIN subcell for MJSC integration and space application}

\author{
Maxime Levillayer \\ ONERA/DPHY, Univ of Toulouse \\ Toulouse, France \\ maxime.levillayer@onera.fr \\ Sophie Duzellier \\ ONERA/DPHY, Univ of Toulouse \\ Toulouse, France \\ sophie.duzellier@onera.fr \\ Hélène Carrère \\ LPCNO, INSA-UPS-CNRS \\ Toulouse, France \\ carrere@insa-toulouse.fr
}

\author{
Inès Massiot \\ LAAS-CNRS \\ Toulouse, France \\ imassiot@laas.fr \\ Thierry Nuns \\ ONERA/DPHY, Univ of Toulouse \\ Toulouse, France \\ thierry.nuns@onera.fr \\ Stéphanie Parola \\ IES, Univ of Montpellier, CNRS \\ Montpellier, France \\ stephanie.parola@umontpellier.fr
}

\author{
Alexandre Arnoult \\ $L A A S-C N R S$ \\ Toulouse, France \\ aarnoult@laas.fr \\ Christophe Inguimbert \\ ONERA/DPHY, Univ of Toulouse \\ Toulouse, France \\ christophe.inguimbert@onera.fr \\ Laurent Artola \\ ONERA/DPHY, Univ of Toulouse \\ Toulouse, France \\ laurent.artola@onera.fr
}

\author{
Chantal Fontaine \\ $L A A S-C N R S$ \\ Toulouse, France \\ fontaine@laas.fr \\ Corinne Aicardi \\ CNES \\ Toulouse, France \\ corinne.aicardi@cnes.fr \\ Guilhem Almuneau \\ LAAS-CNRS \\ Toulouse, France \\ almuneau@laas.fr
}

\begin{abstract}
This paper reports on the optimization of $1 \mathrm{eV}$ dilute nitride solar cells growth conditions. InGaAsN cells were grown by MBE under different conditions (V/III ratio, substrate temperature, surfactant) and were processed without postgrowth annealing. Characterization results suggest that the V/III ratio should be kept above 10 and that using $B i$ as a surfactant does not improve the cell performances. Our best InGaAsN cells exhibit $J_{s c}$ and $V_{\text {oc }}$ values of $7.9 \mathrm{~mA} / \mathrm{cm}^{2}$ and $0.375 \mathrm{~V}$ respectively, under AM0> $870 \mathrm{~nm}$ and without ARC.
\end{abstract}

Keywords-InGaAsN, IeV cell, MJSC, dilute nitride, space applications

\section{INTRODUCTION}

Multijunction solar cells (MJSC) based on III-V semiconductors offer today the highest photovoltaic efficiencies as illustrated by the $47.1 \%$ record held by a 6junctions cell under concentration [1]. Consequently, those cells are of prime interest for energy harvesting in space systems where $\mathrm{W} / \mathrm{kg}$ is the key parameter. However, most efficient MJSC remain at laboratory scale and require complex mechanical processing steps such as substrate report or wafer bonding. These steps are difficult to implement at the industrial scale, which explains the current interest for monolithic growth. Indeed, today's market for high performance MJSC for space is dominated by $\mathrm{GaInP} /(\mathrm{In}) \mathrm{GaAs} / \mathrm{Ge}$ trijunction cells lattice-matched to their substrate, with $28-30 \%$ efficiency.

Theoretical calculations of the optimal bandgap combination pointed out the need to develop a $1 \mathrm{eV}$ subcell to improve spectral overlapping [2]. This subcell could replace Ge as the bottom cell in the current state-of-the-art trijunction or be integrated within a 4-junctions to tackle the theoretical efficiency limit of 38 and $41 \%$, respectively. Dilute nitrides have been studied as potential candidates for this application as nitrogen induces a high bandgap bowing coefficient for small $\mathrm{N}$ concentration [3]. Tuning In and $\mathrm{N}$ composition in the InGaAsN quaternary allows then to lower the bandgap while remaining lattice-matched to GaAs or Ge substrates.
However, the growth of dilute nitride semiconductors was proven to be difficult because of the small size and the high electronegativity of the nitrogen anion leading to the formation of $\mathrm{N}$ induced defects detrimental to the cell properties $[4,5,6]$. For molecular beam epitaxy (MBE), a study pointed out the necessity of growing InGaAsN within a $420-480^{\circ} \mathrm{C}$ temperature window to ensure a high quality two-dimensional growth [7]. The other important growth parameter is the ratio between elements V and III approximated here as the As/III beam equivalent pressure (BEP) ratio. Indeed, As overpressure is reported to have a strong impact on the optical and electrical properties of InGaAsN as it affects the $\mathrm{N}$ incorporation rate and the $\mathrm{N}$ nearest-neighbour configuration $[6,8]$.

Regarding 1eV subcells, today's main challenge is to reach short circuit current density $\left(\mathrm{J}_{\mathrm{sc}}\right)$ values large enough to satisfy the current matching condition within the MJSC. $\mathrm{J}_{\mathrm{sc}}$ higher than $15 \mathrm{~mA} / \mathrm{cm}^{2}$ have been reported for AM0> $870 \mathrm{~nm}[6]$ and AM1.5> $830 \mathrm{~nm}$ [9] irradiance but both results were achieved with bandgap lower than $1 \mathrm{eV}$ ( 0.93 and $0.9 \mathrm{eV}$ respectively) and $\mathrm{FF}$ values were not reported.

Optimization studies were already conducted by varying one growth parameter ( $\mathrm{T}$ or $\mathrm{V} / \mathrm{III})$ while keeping the other parameters fixed $[6,7]$. However, we can reasonably assume that the optimum couple $(\mathrm{T} ; \mathrm{V} / \mathrm{III})$ depends on the targeted nitrogen concentration and remains yet to be found for a $1 \mathrm{eV}$ dilute nitride. Furthermore, the optimization is usually carried out by considering the properties of the cell after annealing, which can be a complicated step to implement during the MJSC monolithic growth.

Our approach consists then in optimizing the MBE growth of $1 \mathrm{eV}$ InGaAsN alloys that does not require a post-growth rapid thermal processing (RTP). In order to identify the best growth parameters, InGaAsN cells were characterized with various techniques such as external quantum efficiency (EQE), photoluminescence (PL) and $\mathrm{I}(\mathrm{V})$ under dark and AM0 illumination conditions. 


\section{EXPERIMENTAL METHOD}

InGaAsN p-i-n cells were grown by MBE at LAAS-CNRS on 4-inch n-GaAs (001) substrates in a Riber 412 system equipped with a RF valved plasma nitrogen source. The devices consist in a $\mathrm{p}$-i-n GaAs/InGaAsN/GaAs structure including a $\mathrm{n}-\mathrm{Al}_{0.4} \mathrm{Ga}_{0.6} \mathrm{As}$ back surface field (BSF), a p$\mathrm{Al}_{0.4} \mathrm{Ga}_{0.6} \mathrm{As}$ front surface field (FSF) and a $\mathrm{p}+\mathrm{GaAs}$ cap layer (Fig. 1a). InGaAsN growth conditions were changed from one sample to the other (see Table 1) while identical conditions were used for the rest of the structure. In composition was calibrated based on the PL signal of InGaAs quantum wells. Nitrogen composition was controlled through a homemade insitu curvature measurement setup [10] allowing us to tune the $\mathrm{N}$ flow into the growth reactor in order to preserve an adequate $\mathrm{In} / \mathrm{N}$ ratio and remain lattice-matched to GaAs. The composition of the InGaAsN active layer was set to $6.5 \%$ for In and $\approx 2.2 \% \mathrm{~N}$ corresponding to the lattice-matched condition.

AuGeNiAu metallization was carried out on the backside by sputtering and TiAu contacts were deposited on the frontside by e-beam evaporation through patterning photolithography and lift-off steps. Wafers were then annealed at $350^{\circ} \mathrm{C}$ during $90 \mathrm{~s}$ in order to achieve good ohmic contacts. Mesa wet etching was performed using $\mathrm{H}_{3} \mathrm{PO}_{4} / \mathrm{H}_{2} \mathrm{O}_{2}$ and the GaAs cap layer was selectively removed using $\mathrm{C}_{6} \mathrm{H}_{8} \mathrm{O}_{7} / \mathrm{H}_{2} \mathrm{O}_{2}$. No anti-reflective coating (ARC) was deposited. Wafers were finally cleaved in $0.25 \mathrm{~cm}^{2}$ and $1 \mathrm{~cm}^{2}$ cells with grid densities ranging from 0 to $10 \%$. The processed cell structure cutview is shown in Fig. 1b.

TABLE I. INGAASN GROWTH CONDITIONS

\begin{tabular}{|c|c|c|c|}
\hline Sample & Surfactant & Growth Temperature & As/III ratio \\
\hline $\mathrm{A}$ & $\mathrm{Bi}$ & $480^{\circ} \mathrm{C}$ & 12 \\
\hline $\mathrm{B}$ & $\varnothing$ & $480^{\circ} \mathrm{C}$ & 12 \\
\hline $\mathrm{C}$ & $\varnothing$ & $460^{\circ} \mathrm{C}$ & 10 \\
\hline $\mathrm{D}$ & $\varnothing$ & $500^{\circ} \mathrm{C}$ & 10 \\
\hline
\end{tabular}

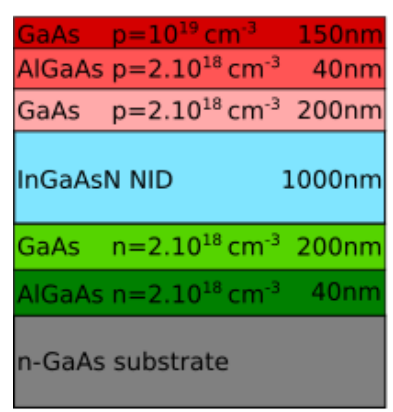

a)

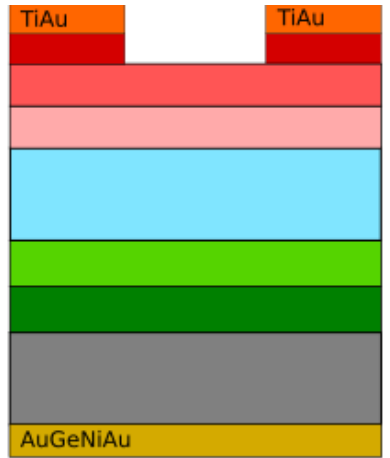

b)
Fig. 1. Structure of the cell after epitaxy (a) and after processing steps (b)

\section{RESULTS AND DISCUSSION}

\section{A. Effect of the growth conditions}

Photoluminescence measurements were performed at $10 \mathrm{~K}$ on as-grown wafers using a Ti-Sa pulsed $950 \mathrm{~nm}$ laser excitation source. Results are shown in Fig. 2a). In addition, we have conducted EQE measurements on solar cells processed from those wafers, as reported in Fig. 2b).

The PL and EQE results show a strong correlation enabling to estimate the InGaAsN bandgap at $1.12 \mathrm{eV}$. Comparing samples A and B, we can see that bismuth used as a surfactant does not improve optical properties. Moreover, slightly larger dark current densities are observed with devices grown with Bi.

Both PL and EQE point out that cells grown with a ratio As/III $=12$ exhibit better optical properties than those grown with a ratio equal to 10 . This difference is likely due to an increase in the density of non-radiative recombination centers in the active layer. The rather large drop in quantum efficiency for lower As/III ratio could originate from degraded carrier collection in the absorbing layer. Indeed, those $\mathrm{p}-\mathrm{i}-\mathrm{n}$ cells rely on a field aided collection regime which can only be guaranteed if the background carrier concentration (BGCC) is low enough in the pseudo-intrinsic layer.
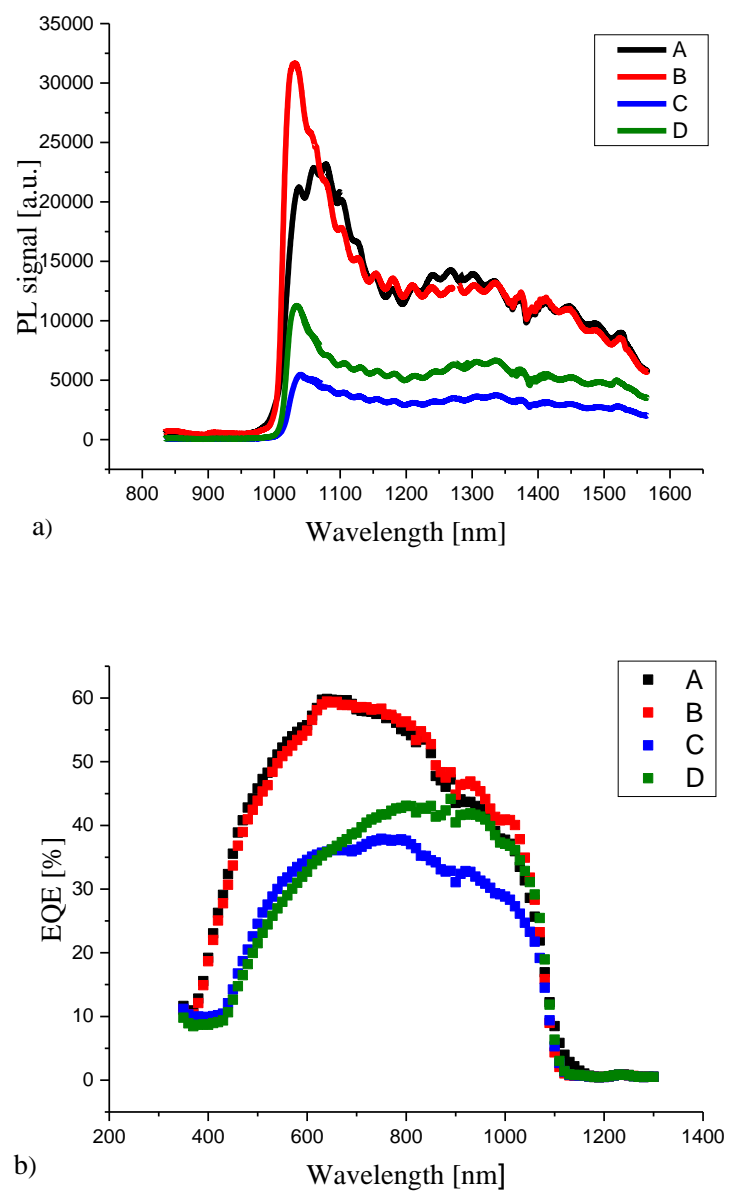

Fig. 2. a) PL spectra of InGaAsN cells, b) EQE of InGaAsN cells 
Relatively high doping concentration can prevent the space charge region to extend within the whole active layer resulting in lower collection efficiency as it was studied in [11]. Reference [12] also reports that under their growth conditions, $900 \mathrm{~nm}$ thick absorber cells are fully depleted whereas 1200 $\mathrm{nm}$ thick ones are not.

Reducing the As/III ratio is then supposed to promote the formation of defects acting as dopants in the InGaAsN layer. On-going $\mathrm{C}(\mathrm{V})$ investigations will provide more details about the BGCC and deep-level transient spectroscopy will be conducted to reveal the electronic nature of the defects.

\section{B. Motivation for processing as-grown cells}

RTP at $700^{\circ} \mathrm{C}$ and $750^{\circ} \mathrm{C}$ were conducted during 30 seconds on $\mathrm{A}$ and $\mathrm{B}$ samples. In contrast to a large part of literature reports $[7,13,14]$, we found that RTP does not improve material properties. No change in dark current density was observed and PL signal was found to be higher for unannealed samples. Additionally, the characteristic InGaAsN blueshift usually seen after RTP was not observed in our case suggesting the good homogeneity of the as-grown dilute nitride layer (no N and In rich phases). Moreover, the evolution of the PL signal with temperature does not show an s-shape for the bandgap energy, implying that the exciton localization is not significant. An hypothesis for this positive result is that defect curing may occur during the growth of the $\mathrm{GaAs} / \mathrm{AlGaAs} / \mathrm{GaAs}$ top layers. Indeed, those layers were grown at $600^{\circ} \mathrm{C}$, which has already been reported to be a highenough temperature to induce self-annealing [15].

\section{I(V) characteristics of the cells}

I(V) measurements were performed under AM0> $870 \mathrm{~nm}$ illumination to evaluate the characteristics of the InGaAsN subcell in operating conditions (integrated in a MJSC). Results show that the I(V) curves confirm the results obtained from PL and EQE measurements. The highest values for $\mathrm{J}_{\mathrm{sc}}, \mathrm{V}_{\mathrm{oc}}$ and FF were measured for samples $\mathrm{A}$ and $\mathrm{B}$ grown with the highest As/III ratio. No clear conclusions could be drawn regarding the effect of the growth temperature and this point is currently under investigation.

The best I(V) characteristics are obtained for the cells grown with a ratio $\mathrm{As} / \mathrm{III}=12$ and without $\mathrm{Bi}$ (sample $\mathrm{B}$ ). We report a $J_{\mathrm{sc}}$ and a $\mathrm{V}_{\mathrm{oc}}$ equal to $7.94 \mathrm{~mA} / \mathrm{cm}^{2}$ and $0.375 \mathrm{~V}$, respectively, under filtered AM0 illumination and without ARC. Accounting for a reflectance both simulated and measured around $30 \%$ in the $870-1300 \mathrm{~nm}$ spectral range, and considering no internal reflection within the MJSC, those cells would exhibit $\mathrm{J}_{\mathrm{sc}} \approx 11.4 \mathrm{~mA} / \mathrm{cm}^{2}$ in operating conditions. To our knowledge, this constitutes the highest PV performances ever reported for unannealed dilute nitride cells.

\section{CONCLUSIONS AND PERSPECTIVES}

We have demonstrated $1.12 \mathrm{eV}$ unannealed InGaAsN cells able to generate $\approx 8 \mathrm{~mA} / \mathrm{cm}^{2}$ under $\mathrm{AM} 0>870 \mathrm{~nm}$ without ARC. Using $\mathrm{Bi}$ as a surfactant and performing a RTP after growth were found not to be useful and even detrimental to some electrical and optical properties. Most importantly, it appears that the As/III ratio has to be kept higher than 10 during InGaAsN MBE growth to ensure a good material quality. Further optimizations have to be carried out and $(\mathrm{In} ; \mathrm{N})$ content has to be increased to further lower the InGaAsN bandgap towards $1 \mathrm{eV}$. Short-circuit density higher than 15 $\mathrm{mA} / \mathrm{cm}^{2}$ will be required to satisfy the current matching condition in MJSC. Finally, InGaAsN subcell integration within a MJSC needs to be demonstrated to ensure its compatibility with the rest of the structure.

\section{ACKNOWLEDGMENT}

We acknowledge the technical support from the LAASCNRS micro and nanotechnologies platform, a member of the French RENATECH network. The authors acknowledge F. Pichot from CTM University of Montpellier for the AuGeNiAu metallization.

\section{REFERENCES}

[1] J.F. Geisz, M.A. Steiner, N. Jain et al. "Building a six-junction inverted metamorphic concentrator solar cell," IEEE J. Photovolt. vol. 8, pp. 626-632, 2018

[2] S.R. Kurtz, D. Myers, J.M. Olson "Projected performance of three- and four-junction devices using GaAs and GaInP," Proceedings of the 26th IEEE PVSC, p. 875, 1997

[3] M. Weyers, M. Sato, H. Ando "Red shift of photoluminescence and absorption in dilute GaAsN alloy layers," Jpn. J. Appl. Phys. vol. 31, pp. 853-855, 1992

[4] R. Kaplar, D. Kwon, S.A. Ringel et al. "Deep levels in p- and n-type InGaAsN for high-efficiency multi-junction III-V solar cells," Sol. Energy Mater. Sol. Cells vol. 69, pp. 85-91, 2001

[5] A. Khan, S.R. Kurtz, S. Prasad, S.W. Johnston, J. Gou "Correlation of nitrogen related traps in InGaAsN with solar cell properties," Appl. Phys. Lett. vol. 90, 2007

[6] V. Polojarvi, A. Aho, A. Tukiainen et al. "Influence of As/group-III flux ratio on defects formation and photovoltaic performance of GaInNAs solar cells," Sol. Energy Mater. Sol. Cells vol. 149, pp. 213-220, 2016

[7] A. Aho, V. Polojarvi, V.M. Korpijarvi et al. "Composition dependent growth dynamics in molecular beam epitaxy of GaInNAs solar cells," Sol. Energy Mater. Sol. Cells vol. 124, pp. 150-158, 2014

[8] E.M. Pavalescu, T. Hakkarainen, V.D.S Dhaka et al. "Influence of arsenic pressure on photoluminescence and structural properties of GaInNAs/GaAs quantum wells grown by molecular beam epitaxy" $J$. Cryst. Growth vol. 281, pp. 249-254, 2005

[9] M.M. Wilkins, J. Gupta, A. Jaouad et al. "Design of thin $\operatorname{InGaAsN(Sb)}$ n-i-p junctions for use in four-junction concentrating photovoltaic devices" J. Photonics Energy vol. 7(2), 2017

[10] A. Arnoult and J. Colin, Patent FR1754616, May 2017.

[11] N. Miyashita, N. Ahsan, Y. Okada "Generation and collection of photocarriers in dilute GaInNAsSb solar cells" Prog. Photovolt: Res. Appl. vol. 24, pp. 28-37, 2016

[12] A.I. Baranov, A.S. Gudovskikh, D.A. Kudryashov et al. "Defect properties of InGaAsN layers grown as sub-monolayer digital alloys by molecular beam epitaxy" J. Appl. Phys. vol. 123, 2018

[13] K. Volz, D. Lackner, I. Nemeth et al. "Optimization of annealing conditions of (GaIn)(NAs) for solar cell applications" J. Cryst. Growth vol. 310, pp. 2222-2228, 2008.

[14] N. Miyashita, Y. He, N. Ahsan, Y. Okada "Anneal mediated deep-level dynamics in GaInNAsSb dilute nitrides lattice-matched to GaAs" $J$. Appl. Phys. vol. 126, 2019

[15] E. Pavalescu, T. Jouhti, M. Dimitrescu et al. "Growth-temperaturedependent (self-)annealing-induced blueshift of photoluminescence from $1.3 \mu \mathrm{m} \mathrm{GaInNAs/GaAs} \mathrm{quantum} \mathrm{wells"} \mathrm{Appl.} \mathrm{Phys.} \mathrm{Lett.} \mathrm{vol.} \mathrm{83(8),}$ 2003 